
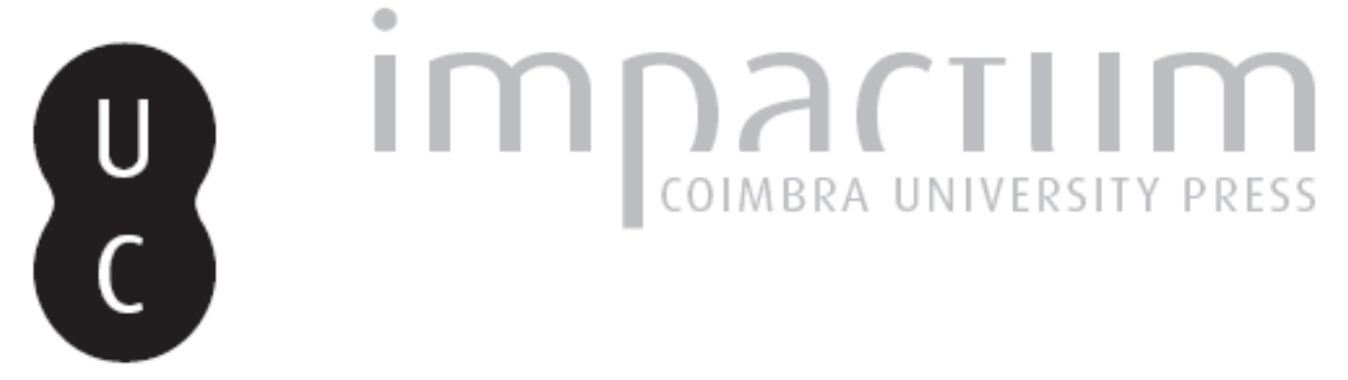

\title{
Lamego, futura cidade humanista, segundo Salvador Fernandes
}

Autor(es): $\quad$ Ramalho, A. Costa; Silva, Augusta Oliveira e
Publicado por: Associação Portuguesa de Estudos Clássicos; Instituto de Estudos Clássicos

URL persistente:

URI:http://hdl.handle.net/10316.2/30394

DOI: DOI:http://dx.doi.org/10.14195/0872-2110_52_11

Accessed : $\quad$ 26-Apr-2023 15:19:35

A navegação consulta e descarregamento dos títulos inseridos nas Bibliotecas Digitais UC Digitalis, UC Pombalina e UC Impactum, pressupõem a aceitação plena e sem reservas dos Termos e Condições de Uso destas Bibliotecas Digitais, disponíveis em https://digitalis.uc.pt/pt-pt/termos.

Conforme exposto nos referidos Termos e Condições de Uso, o descarregamento de títulos de acesso restrito requer uma licença válida de autorização devendo o utilizador aceder ao(s) documento(s) a partir de um endereço de IP da instituição detentora da supramencionada licença.

Ao utilizador é apenas permitido o descarregamento para uso pessoal, pelo que o emprego do(s) título(s) descarregado(s) para outro fim, designadamente comercial, carece de autorização do respetivo autor ou editor da obra.

Na medida em que todas as obras da UC Digitalis se encontram protegidas pelo Código do Direito de Autor e Direitos Conexos e demais legislação aplicável, toda a cópia, parcial ou total, deste documento, nos casos em que é legalmente admitida, deverá conter ou fazer-se acompanhar por este aviso.

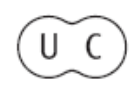




\section{Boletim de}

\section{Estudos Clássicos}

Associação Portuguesa de Estudos Clássicos Instituto de Estudos Clássicos

Coimbra

Dezembro de 2009 


\section{LAMEgO, FUTURA CiDADE HUMANISTA, SEgUNDO SALVADOR FERNANDES}

Na carta ao impressor Antonio Tellez de Toledo, o humanista Salvador Fernandes exorta-o a não esquecer a sua arte, por falta de encomendas de trabalhos impressos.

O impressor é um artista tão hábil que a sua fama pode atrair autores que confiram à cidade de Lamego a reputação das cidades cultas da Itália, para além das suas belezas naturais.

Isto consta das afirmações de Salvador Fernandes numa carta que acompanha a Oração latina e que o mesmo professor de Direito pronunciou em 1509, provavelmente em Fevereiro, pois o seu cólofon vem datado de 1 de Março de 1509.

Essa Oração é uma saudação do humanista ao $2^{\circ}$ marquês de Vila Real, D. Fernando de Meneses, a sua mulher D. Maria Freire, a marquesa, e ao jovem filho de ambos, D. Pedro de Meneses, conde de Alcoutim, na sua entrada em Vila Real.

O texto encontra-se num manuscrito da Biblioteca da Universidade de Coimbra e foi publicado com tradução portuguesa, por A. Costa Ramalho, Latim Renascentista em Portugal, Lisboa, Fundação Calouste Gulbenkian/Junta Nacional de Investigação Científica e Tecnológica, ${ }^{21993,}$ pp. 98-117.

Sobre Salvador Fernandes e a sua Oração de Vila Real, ver A. Costa Ramalho, Estudos Sobre o Século XVI, Lisboa, Imprensa Nacional-Casa da Moeda, $2^{a}$ edição aumentada, 1983, pp. 21-27.

Segue-se a transcrição parcial da carta ao impressor:

\section{Impressori salutem}

(...) hac de re te oro ac exoro, ut solitas uires accingas, moramque atque segnitiem Romano animo rumpas. Itaque et te et me in lucem pandas, ne artificiosa gloria tua amplius sepulta iaceat: tua mira opera industriaque Lamaecensem ciuitatem magnifecisse uideberis, ut praeter dotes mirificas quas habet, celebribus Italiae urbibus exaequetur cum in eius limitibus uir tantae sollertiae (qualis es) inueniatur. Immo moram trahat, qui ferreo stilo 
haec et maiora edat. Fac precor operamque da. Quod si feceris, ut fore spero, tibi per sibyllinos dies obnoxius ero.

Vale.

AMÉRICO DA COSTA RAMALHO E AUGUSTA OLIVEIRA E SILVA 